\title{
OBSERVATIONS BY A "FRIEND OF THE COURT"
}

\author{
Edward PoKornx*
}

In Michigan, the Wayne County Circuit Court has jurisdiction over divorce matters. ${ }^{1}$ By statute in $1929^{2}$ and Rule of Court the office of "Friend of the Court" was created. The present article discusses problems of modification of custody and maintenance orders in divorce cases from the standpoint of the Friend of the Court.

First then as to the size of the problem. The population of Wayne County is approximately 2,000,000. Divorce applications average 4,000 a year. In many of these cases decrees for maintenance and custody are necessary. In about $20 \%$ of the cases in which decrees for maintenance are entered petitions are later filed for a modification due to a change in circumstances. In about $14 \%$ of the cases where custody orders are entered petitions are later filed for a modification due to a change in circumstances.

It is obvious that there is need for the court before making a decision to obtain full and complete information regarding the changes in circumstances in each case. This is the reason for the creation of the office of the Friend of the Court. Under the methods in effect prior to 1929 the orthodox litigation procedure was employed to place the facts before the judge. One party might cite the other for contempt or file a petition for a change of custody. Counsel for the parties would then proceed to secure witnesses, affidavits and go through the somewhat ponderous process of preparing for the trial. On the day set for the hearing the court would be obliged to listen to evidence and to apply the various rules excluding legally nonrelevant information. Counsel would examine, cross examine, make objections, take exceptions. After expenditure of necessarily considerable time a decree would be entered. Sometimes months would elapse. The present practice is useful if only because it permits greater expedition in disposing of these complicated matters.

Saving time may be of advantage to the court and to the parties. Today the spouse who desires a modification of a maintenance or custody order files a praecipe and a petition. Within two or three weeks the matter is referred to the Friend of the Court. An investigator from the office of the Friend of the Court proceeds to gather data.

* LL.B., I905, Detroit College of Law. Member of the Michigan Bar. Friend of the Court for the Circuit Court for the County of Wayne, State of Michigan, since 19r8. Attorney for the Legal Aid Bureau of the Detroit Bar Association, 1909-x919. Member of the Board of Directors of the Children's Aid Society.

${ }^{1}$ Mich. Comp. Laws (1929) \$12734. $\quad{ }^{2}$ Mich. CoMp. Laws (1929) \$12783.

${ }^{3}$ For a more detailed description of the Friend of the Court see The Evolution of the Office of Friend of the Court (I935) Mrchigan Judicial Council, Fiftri Ann. Rep. 6i ff.; Pokorny, Practical Problems in the Enforcement of Alimony Decrees (1939) 6 Law And Contemp. Prob. 274. 


\section{Problents in Fact Gathering}

This process of fact gathering is not simple. Personal points of view must be dealt with. Examples of these human factors appear in the form of letters.

One irate wife who is a stickler for observance of support orders wrote:

"What a friend you are. The Court ordered my husband to pay me $\$ 15.00$ a week on Mondays. You let him pay it on Fridays. I want it on Monday and if you don't do something about it, I will take the law in my own hands. So look out."

In another case, a husband who was in arrears sought modification of a support order for a minor child. The ex-wife, who lived in another city, indulged in considerable correspondence and in one of her letters complained:

"I feel you could have paid me more than $\$ 560.00$ if you were that way inclined. The thief goes on stealing year after year until he is convicted. The fool goes on year after year doing the same thing over again and again, never acquiring any wisdom. You have had five years experience in this matter. It saddens and discomforts me to liken you either to the thief or the fool. Remember that I married you because I loved you and nothing else really matters much."

The sources from which the investigator endeavors to obtain the data are: the divorced parents; the children; the persons in whose home the children are living; the neighbors. The type of information he collects bears a relation to the reasons for requesting a modification. The earning capacity of the husband, a vital fact, is determined very simply. The investigator sends to the husband's employer a printed form requesting information as to the employee's earnings, for a given period of time. A self-addressed stamped envelope is enclosed to facilitate a reply. Rarely is this information challenged by the employee.

In one case a mother petitioned the court to modify the decree and to require the ex-husband to pay doctor's bills because the child developed crossed eyes and needed medical treatment. The husband had become indifferent and refused to cooperate with the department in the investigation of the facts alleged in the petition. The investigator obtained statements from the doctor as to treatment, the possibility of cure, the cost thereof. The mother's inability to meet the expenses arose because of the insufficient allowance the father was paying for the support of the children. When the case came up for hearing the court reviewed the Friend of the Court's report, making the following comment:

"In no place does the father challenge the findings of the Friend of the Court as to the physical condition of the child or its need for medical services. That the controverted fact resolved itself as to the husband's earnings. He states again in the petition that he is currently employed at approximately $\$ 26.00$ per week, against which we have the report of the Friend of the Court of the man's earnings showing an average of \$52.09 per week."

The value to the court of facilities for verifying such facts is obvious.

Another problem in fact gathering is presented where distance separates the parties. In Michigan cooperation among the Friends of the Court in the various counties is helpful in overcoming this obstacle. 
The Friend of the Court had been awarded custody of two minor children in a final decree. Thereafter, upon the request of the husband, one of the children was temporarily placed in his custody, to be returned at the opening of the school term. The husband refused to comply with this condition. The orthodox practice in the event of such a refusal would have been to bring the husband promptly before the judge who entered the decree. A different and more friendly approach was adopted. Another Friend of the Court in the county where the child and father were residing, about roo miles from Detroit, was appealed to. This Friend of the Court supplied sufficient information to permit a contact with the father by long distance telephone. In conversation, we were able to explain to him the seriousness of defying the order of the court. He agreed to surrender the child to a deputy sheriff attached to this office, who, with the ex-wife, went to the home of the exhusband and took possession of the child and delivered him to his mother, to be returned to his home and immediately placed in a very fine boarding school. It was obvious that the father's reluctance to surrender the custody was based on his attachment and affection. It was a real sacrifice for him to part with his child.

There is still another significant factor in handling modification requests. Occasionally immediate action must be taken if the welfare of the children is to be considered.

In one case the child was a nine-year-old. The parents had been divorced. The father had remarried. Custody of the child was awarded to the mother, whose morals became so bad that the child had lived temporarily in foster boarding homes. He had developed behavior problems. For the preceding two years the child had been placed with his paternal grandparents. The grandmother became ill and was unable to continue to look after him. She notified the Friend of the Court immediately to remove the child from her home. Here was an emergency with which the orthodox machinery of the law was not prepared to cope. The mother was contacted and she refused to take any action. The child's father was in military service. A telegram to the Army chaplain produced an immediate response. The father would accept the child in his home. An officer arranged with the Travelers' Aid Society to supervise the child's traveling to a distant point. In due course of time, the decree will be modified to meet the changed circumstances. Such are the problems which occupy the time of the fact investigator.

Eventually the facts are gathered and a report is prepared. This report is examined by a supervisor who may approve or require that further study be made. When the report is complete, recommendations are appended, and notices are sent to the attorneys stating the substance of these recommendations and setting the date for the hearing. On the day, the parties appear before the judge. He reads the report, listens to the remarks of counsel if there are any objections, and decides the issues. He may adopt the recommendations, reverse or amend them. Under this procedure not over half an hour of the court's time is consumed disposing of the point in controversy, where formerly hours might be involved. 
We have been accustomed to hear criticisms of the administration of justice in this country to the effect that it is slow, expensive and cumbersome. The Friend of the Court in this class of case is one answer to all three of these objections. He saves time for court, child, parent. He is available for poor people as well as others. He can protect the interests of the child in cases where the parents or others are indifferent and do not care to raise issues for judicial determination. The child may not be able to set in motion the machinery of the law to obtain relief. The Friend of the Court performs this service for him. But there is a further advantage. The quality of the judicial process in deciding the issues is improved because of a more adequate means of sifting the considerations which prompt one of the ex-spouses to ask for a modification of the decree. The present article provides the reader with a series of illustrations of this process; cases in which the motives of the parties were made clearer to the court.

\section{Factors Affecting Modification}

The judge who decides applications for modifications of decrees relating to children of divorced parents has a difficult task. His discretion is neither rigidly limited by rule of law nor completely unfettered. Rather it is exercised in the light of the surrounding circumstances with certain objectives in mind. The modification should be fair to the ex-husband, to the ex-wife, to the children. The process of balancing and evaluation requires much background material to explain the legally relevant facts.

Fairness to the ex-wife is a factor which has influenced judges from the time of the Code of Hammurabi and perhaps before." "There is no rigid rule of division of property and the security of a living for the wife should be a major consideration. . . . The division must be equitable." Where the case is contested by the husband, he may be in a position to prove indiscretions on the part of his wife. $\mathrm{He}$ may use or threaten to use this information as a club over her head. She is confronted with the horrifying thought that she might be deprived of the custody of her children, should she fail to accept a proposed settlement offered by her husband. Sometimes she agrees to the entry of a decree awarding her the custody of the children and ordering the father to pay an inadequate sum for their support. Then it may develop that the wife made a very bad bargain and deeply regrets it. She

\footnotetext{
- Code of Hammurari (Harper's Trans. 1904): \$137. "If a man set his face to put away a concubine who has borne him children or a wife who has presented him with children, he shall return to that woman her dowry and shall give to her the income of field, garden and goods and she shall bring up her children; from the time her children are grown up, from whatever is given to her children they shall give to her a portion corresponding to that of a son and the man of her choice may marry

5145. "If a man take a wife and she do not present him with children and he set his face to take a concubine, that man may take a concubine and bring her into his house. That concubine shall not rank with his wife."

3148. "If a man take a wife and she become aftlicted with disease, and if he set his face to take another, he may. His wife, who is afflicted with disease, he shall not put away. She shall remain in the house which he has built and he shall maintain her as long as she lives."

- Brown v. Brown, 297 Mich. 24, 296 N. W. 867, 868 (1941).
} her." 
may have married the man with whom she committed indiscretions. He may be reluctant to support somebody else's children. In the interest of maintaining harmony in the home, the wife will seek advice of a lawyer, who will advise her to file a petition to modify the decree. Notwithstanding the former agreement of the parties, should the father of the children have capacity to contribute a larger sum, the court invariably orders the father to do so. ${ }^{b}$ The court is concerned with adequate support for the children, either by supplemental contributions by the stepfather or a reconsideration on petition for modification.

But the desires of the mother to have the child are not the only factor which deserves consideration. At the time of the entry of one decree, the husband, wife and three-year-old girl were living in the same home. The husband was the plaintiff in the suit and charged his wife with extreme cruelty and the use of vile and obscene language in the presence of the husband and the child. He claimed that she remained away from home until 3:00 or 4:00 in the morning, after having made the rounds of the beer gardens. Apparently the wife, age twenty-eight, was content to live that kind of a life. She was even willing to sacrifice the companionship and opportunity of supervising the upbringing of her daughter. She worked in a war factory and enjoyed a good defense worker's wage, which exceeded the husband's contribution towards support when they were living together. She lacked sufficient willpower to make use of her opportunities in the saving of money and building for the future. She enjoyed the thrill of spending money and meeting other people. Very soon after the entry of the decree, which awarded custody of the child to husband, the mother's instinct asserted itself and she yearned for association with her daughter and for the responsibilities of motherhood. The mother's motive, undoubtedly, was sincere and she hoped to convince the court that it would be for the best interest of the child if she continued her employment as a defense worker and during her hours of employment, either on the day or night shift, a woman living in the neighborhood would look after the child. Obviously, it was extremely difficult to convince the mother that her plan was not for the best interest of the child and that she should continue to forego her daughter's company until she could work out a more suitable plan for her upbringing.

Another factor, fairness to the ex-husband, requires that a loss of earning power be taken into consideration.

A Decree of Divorce incorporated the substance of property settlement agreement between the parties. This provided for the payment of a certain sum of money per week for the support of the wife and two children. Both parties remarried. The ex-husband's wage income dropped from $\$ 125.00$ to $\$ 100.00$ per week. His present wife was about to become a mother. The ex-wife employed her mother to look after the children while she worked in a war factory, earning $\$ 67.00$ per week. The ex-husband filed motion to reduce allowance. He believed that the ex-wife's employment and the legal requirement upon her new husband to support

-West v. West, 24I Mich. 679, 217 N. W. 924 (1928). 
her, created two reasonable and logical grounds to justify granting him relief. The ex-wife opposed the reduction solely on the ground that the cost of living has increased to such an extent that the original order should not be reduced.

Again, normal affection of the father for his child is a factor which may not be ignored. In still another case, custody of the minor child, then of the age of one year, was granted to the mother with the privilege of temporary custody one afternoon a week after the child had reached the age of two years. The father was ordered to pay $\$ 6.00$ per week. Both parties remarried. The child is now eight years of age. The father charged that the mother had changed the name of the child to that of her present husband. This is his objection to compliance with the existing decree. He has no children by his present wife. He feels paternal urgings to associate with his own flesh and blood. He assumes that as a father he is possessed of several inherent rights that are bestowed by nature and cannot be denied him. He petitioned the court for a modification of the decree and that he be granted temporary custody of the child during three summer months. There never was any objection on his part towards the amount of money that he was paying towards the support of the child. The court granted his request to the extent of the child's retention of the father's name.

\section{Exercising Judicial Discretion}

A good example of the exercise of discretion by the court in a modification case is contained in the following latest pronouncement of the Michigan Supreme Court: ${ }^{7}$

"In February, 1927, the plaintiff [wife] obtained an uncontested decree of divorce from defendant and was given the care and custody of their minor son, Jack.... The decree granted her alimony of $\$ 10.00$ a week for the care and maintenance of said child until he attained the age of 16 years. . . . Five days after obtaining her divorce, the [wife] remarried and four children were born of such venture. The son Jack went through school and was graduated from high school under the surname of his stepfather....

"On the plaintiff's petition an order for defendant's attachment for non-payment of alimony was entered Jan. 6,1928 and on Jan. $23, \mathrm{r} 928$, he filed a petition to modify the decree by cancelling past-due and future alimony. ... [Nothing came of both proceedings. The case lay dormant for a period of fourteen years when the wife filed a new petition for an order to show cause why the husband should not be held in contempt for non-payment. Five days later, he filed a petition to modify the decree by cancelling all accumulated unpaid alimony. Both proceedings were brought together for hearing. 'The court denied the husband's petition to cancel the alimony and directed court's officer to institute contempt proceedings. Appeal was taken to the Supreme Court. Writer.]

"It was shown that defendant had paid only $\$ 25.00$ in I927 and \$50.00 in I94I, and that a balance of about $\$ 5,775.00$ remained due and unpaid under the decree at the time the son, Jack, became 16 in 1938 . The testimony of the plaintiff and defendant as to why the alimony was not paid is in direct conflict. Defendant claimed that after the decree of divorce was entered in 1927 , he was not permitted to visit or talk with his son, and

${ }^{7}$ Chipman v. Chipman, 308 Mich. 578, 14 N. W. (2d) 502, 503, 504, 505 (1944). 
that plaintiff agreed orally that if he would not visit the son, she would not collect the alimony. Plaintiff denied making such agreement and claimed that she had used her best efforts to make collection. The record shows that defendant remarried in 193r; that, except for about two years spent in Maine and a few months at Croswell, Michigan, he had resided continuously in the City of Detroit; that he was unemployed for about two years during the depression; that he was earning $\$ 38$ to $\$ 40$ a week; that he had no property except about $\$ r 00.00$ in Government bonds. Prior to his becoming 16 in 1938 , the son, Jack, had been supported by plaintiff and her second husband . . . whose surname he had assumed.

"The principal question before the trial court and before us on this review is whether or not there was such a change in the circumstances and conditions of the parties as to justify modification of the divorce decree as regards alimony. Baxter v. Baxter, 296 Mich. 567,296 N. W. 68r. While recognizing the general rule that the amendment of a divorce decree is discretionary with the trial court, nevertheless, we are convinced that had we been sitting as the trial court in the present case, we would have reached a different conclusion. The rights of the son are not involved, as the alimony allowance terminated when he became 16 , and apparently he is now self-supporting. Through the present contempt proceedings plaintiff is endeavoring to collect unpaid alimony to reimburse herself for moneys which she and her second husband expended for the support and maintenance of the son. Defendant promptly answered such proceedings by filing petition to amend the decree by cancelling the unpaid alimony.

"Plaintiff had no absolute right to the accumulated alimony, as the amount thereof could be changed from time to time and reduced in the discretion of the court. ...

"We note that the procedure in the Loomis case, ${ }^{[8]}$ where the plaintiff filed petition for attachment for non-payment of alimony and defendant answered with a motion to amend the divorce decree, was substantially the same as that in the present case, where plaintiff began contempt proceedings and defendant countered with a petition to amend the decree.

"Plaintiff certainly was dilatory in her efforts to collect the alimony from year to year. Her failure for a period of nearly 15 years to use reasonable efforts to obtain payment through the means provided by law, lends credence to the defendant's claim that she agreed not to collect it if he would agree not to visit the child. Apparently she elected to support the child herself rather than to compel defendant to contribute the decreed alimony for his support. We do not overlook the fact that she remarried within five days after divorcing defendant, but the four children resulting from such second marriage cannot operate to impose any additional obligations on defendant. Her claim for alimony long past due, which she failed to use reasonable efforts to collect, is in large part a stale claim....

"In view of the defendant's present financial condition and the facts and circumstances shown by the record, it certainly would be inequitable and purposeless to saddle him with a debt of $\$ 5,775$ for the reimbursement of plaintiff, which debt he apparently would never be able to pay. We are impressed with the recommendation of the Friend of the Court that, upon defendant's paying the plaintiff $\$ 300$, the balance of the accumulated alimony be cancelled. The record clearly indicates such a change in the circumstances and condition of the parties as to justify the amendment of the decree by cancelling all unpaid alimony except the sum of $\$ 300$ and the $\$ 20$ per month allowance pending this appeal. Such amounts are all that defendant, in his present financial condition, can rensonably be expected to pay.

${ }^{8}$ Loomis v. Loomis, 273 Mich. 7, 262 N. W. 33 I (1935). 
"We conclude that, upon defendant's paying to the Friend of the Court for plaintiff's benefit, the $\$ 20$ per month, pending this appeal, as provided by the trial court's order of February $4, x 943$, and paying the further sum of $\$ 300$ in monthly installments of $\$ 20$ each, the balance of the accrued and unpaid alimony shall be cancelled.

"The order of the trial court entered January Ir, r943, is vacated and set aside and a decree may be entered in this court in accordance with this opinion. Such decree shall remand the case to the trial court for such further proceedings as may be necessary. In view of the financial condition of the parties no costs are allowed."

\section{The Change in Circumstances}

The problem of whether there has been a sufficient change in circumstances to justify the court in modifying the original decree is frequently encountered by the Friend of the Court, an illustration of which is offered by the following case. The parties were married in r930. A daughter was born in r933. The husband obtained an uncontested decree of divorce in 1938. The wife was awarded custody of the minor child until she arrived at the age of 17 years. The husband was given the privilege of visiting the child once each week. He was ordered to pay $\$ 8.00$ per week for the support of the child. Soon after the original decree was entered, the husband filed a petition to extend the time of his visits and his temporary custody privilege, which was a period of four hours during the day. Both parties remarried within a year after decree was entered. On the first petition, no judicial action was taken. Later, a second petition was filed by the husband, seeking custody of the child for a period of two months during the summer vacation and for relief from payment of allowance during such period. It appears that the motivating cause was the fact that the husband lived a distance of fifteen miles from the former wife's home and, because of the restricted hours of possession, limited the child's presence in his home to about one hour, and when he visited the child at the mother's home, he was compelled to do so in the child's bedroom and further that the wife attempted to obtain his consent to the adoption of the child by the mother's present husband. The Friend of the Court's report indicated that there was considerable bitterness between the parties regarding visitation and possession of the child and expressed the view, as result of its study, that "it would be extremely difficult to make any order of visitation that would be agreeable to the parties of the suit." From an amended order enlarging the temporary custody privilege from Friday evening until Sunday evening of each week and for one month during the summer, appeal was taken. On appeal, the court stated:

"Our first consideration is for the welfare of this minor child. The desires, claims, and affections of the parents must yield to the course that is best for the welfare, happiness, and future of the child. We have repeatedly recognized the rule that children of divorced parents are, in a sense, wards of the court and their welfare must be guarded [citing cases]. The original decree was obtained by plaintiff in an uncontested suit. We, therefore,

'Sims v. Sims, 298 Mich. 49r, 496, 299 N. W. 158, 159 (1941). 
assume such decree, when entered, was, so far as the possession and visitation of the child is concerned, proper and satisfactory to both the court and plaintiff.

"The only question before us is whether there has been any change of circumstances or new facts arising since the original decree was entered which warrant the modification granted ... petitions of the parties and report of the Friend of the Court do not show any material new facts or change of circumstances. ...

"Furthermore, the child is a little girl of tender and impressionable age and is now apparently well cared for by her mother in a good home environment. She should remain with her mother, with only limited possession and visitation privileges by the father as provided in the original decree. Any change at this time in the original decree, as regards possession and visitation of the child by the plaintiff, will only accentuate the bitterness and strained relations between the parties and may result detrimentally to the child. It is difficult to reconcile plaintiff's alleged interest in the welfare of his child with his failure to make the required weekly payments for her support, at a time when his income was amply sufficient.

"As the record shows no new facts and no material change of circumstances arising since the original decree was entered which justify the modification as regards plaintiff's right of possession and visitation of the child, the amended decree should be vacated. . . ."

\section{Relatives of the Child Become Interested Parties}

It is not unusual for relatives of children to become interested in their welfare when their home life has been disturbed by separation and divorce of the parents. One case involved the custody of a boy nine years of age. The parents were divorced in $193^{8}$ and the boy was awarded to the maternal grandparents. The father was ordered to pay one-half of the supporting cost. The wife remarried four months after entry of decree. Ten months after decree she filed petition to modify decree so as to award her custody of the child. From a denial of modification, petitioner appeals. This disposition, upon appeal, as well as the Friend of the Court's report (in part) appears from the following opinion: $:^{10}$

" "This report of the Friend of the Court, pertains to the petition of Harriet Smith to gain custody of her son Thomas Ritter, age 9 years, who now is and always has been in the care and custody of the maternal grandparents of said child. The mother of the child ... now seeks custody of her child.

" It appears that the parents of the child are divorced, and that now the mother of the child having recently remarried ... and having a home of her own wants to gain custody of her child and that the grandparents oppose such change of custody except upon order of the court.

" 'From the report of Catherine McCuaig, county juvenile court officer of Emmett County, which report is hereto attached, and from the testimony taken in open court, it appears. that the child since birth, by the consent of the mother of the child, and court approval, has been in the immediate care and custody of said maternal grandparents. The home life of the child now is and always has been ideal; ample home grounds in which the child can play, home surroundings and environment good; religious training not neg. ${ }^{10}$ Smith v. Ritter, 292 Mich. 26, 289 N. W. 316 (1939). 
lected; schooling and educational advantages all that could be desired or expected. It is the child's natural home. He has never known any other home, and the mother makes no objection as to the proper bringing up that the child enjoys and has always had. There is the best of kindly feeling between the mother of the child and her parents, who have always had the custody of the child.'

"Plaintiff appeals and contends that under the provisions of 3 Comp. Laws 1929, §12852, she is entitled to the care and custody of the minor child of the parties.

"We are of the opinion that the result to be attained in the instant case is controlled by the principles enunciated in Weiss v. Weiss, I74 Mich. 43I, I40 N. W. 587, 588, where we said:

" "It can be said of the foregoing section, taken as a whole, that it was intended as a general guide for the courts when in doubt as to which of the parents is the more fit, or when neither is shown to be unfit. It has been construed as meaning that prima facie the mother is best entitled to the custody of very young children, favoring her that respect, and as meaning there should be preponderating reasons in favor of the father before it is otherwise provided. . . .

" "The statute in question has never been construed as qualifying or restricting the inherent, broad, discretionary powers of a court of chancery to adjudicate as to the custody and control of children whose interests are before it, according to the varying elements for consideration arising in each case, and to make such disposition of each child as its best interests appear to demand.

" "The fact that the parents are equally good, or equally bad, or even that one in some respects may be better than the other, is not necessarily the final test. Other considerations bearing on the welfare of the child may turn the scale.

" "While the wishes and affections of the parents for the child are not to be ignored, they are a secondary consideration. The primary consideration is the welfare and happiness of the child, from the standpoint of education, moral and religious training, good influences, care, kind treatment, pleasant environments, and future prospects.' "

\section{Other Significant Factors}

Difficulty is encountered in determining the weight to be given to certain additional factors. Children of divorced parents always have been and always will be the sufferers when, after decree of divorce is granted, the parents move to different cities. There are few questions more troublesome than when this happens.

At the time of the hearing of the proofs in the divorce suit, it may not be known that, at some distant day, economic and social conditions may demand a change of residence. The power of the court to modify custody provisions is not always the solution to such troublesome problems.

As pointed out in one recorded case, the parties had made a property settlement, confirmed by the court and incorporated in the decree. The wife was given custody until the child attained the age of 16 years. The husband was given the right to have the child visit him one day each week and a portion of the summer vacation, when it does not interfere with the child's education. When the original 
decree was entered, both parties lived in the same city. Later the parents moved to different cities, in the same state, approximately 200 miles apart. The wife was charged with persistently refusing to allow the child to visit the father, in accordance with the terms of the decree. An Order to Show Cause was issued charging her with contempt. She replied by filing a petition to modify the decree by eliminating her husband's custody privilege from the decree. This action on the part of the wife is indicative of an anti-social complex that, right or wrong, she is going to have her own way when it comes to routine and upbringing of her child.

The court made an unsuccessful effort to bring the parties to an agreement. An order was entered modifying the provisions as to custody, which granted to the husband the right to have his child at least four days during a certain month and four days each alternating month thereafter and for a period of two weeks during the summer period. The wife appealed. The court said $:^{11}$

"When a divorce is granted, the court 'may determine with which of the parents the children, or any of them, shall remain.' 3 Comp. Laws 1915, \$11407. The provision in Section $\operatorname{rr}_{4} 84$ that prima facie the mother is entitled to the care and custody of all children under $x 2$ years of age has been treated as expressive of the legislative intent in such cases.... While the welfare of the child must always be considered, 'access to the child by the parent denied custody is an important right.' Kane v. Kane, 24I Mich. 96, 99, 216 N. W. $437,438$.

"There are few more troublesome questions than that here presented. Trial judges differ much in their views regarding such a provision. Some are inclined to think that it is for the best interest of the child that the parent deprived of its custody should not thereafter see it, while others are strongly of the opinion that, if possible, it should grow to manhood or womanhood with retained affection for the parent in whose custody it has not been placed.

"There are perhaps no two of the members of this court who, had they been sitting as trial judges in this case, would have embodied a like provision in this decree. Mr. Justice Clark said in Gilbert v. Gilbert, 242 Mich. $x 78,180,218$ N. W. 654, 655: 'The circuit judge had the advantage, most important in a controversy of this sort, of personal observation of the parties.'

"We are unwilling at this time to substitute our judgment for his, particularly in view of the fact that if it is at any time made to appear to him that the above provision is not for the best interests of the child, when considering the rights of the parents, a new decree may be made by him."

\section{Conclusion}

Generalization about "what is the law" from such widely differing fact situations is difficult. One may as well recognize the futility of statements of law that appear to simplify the solution of a particular case by declaring, for example, that the mother, if a suitable and proper person, is invariably entitled to the custody of her child; such a generality, and innumerable others couched in terms of specific factors, is not supported by the decisions. Perhaps all that one can say is that each

${ }^{21}$ Smith v. Smith, 252 Mich. 543, 233 N. W. 409, 410 (1930). 
case is viewed on its own merits and decided conscientiously and fairly in the light of the facts and the weight given to the various factors. This task of decision is rendered less complicated by the Friend of the Court who is in a position to gather information, evaluate it and save time. The modern trend toward aids of this sort for the judicial process is practical. There seems no good reason why the problems of the children of divorced parents should be made greater by attempting to solve them only through orthodox legal machinery which is not particularly adapted to them. The Friend of the Court justifies its existence by an unobtrusive but ceaseless vigilance with respect to innumerable details any one of which, in a given case, may become the turning point. 